\title{
The Relationship between Personal Hygiene and Household Insecticide Use with Parkinsonism on Farmers at Juhar Ginting Sadanioga
}

\author{
Andin Rizqika Aliunputri, Taufik Ashar, Rahayu Lubis \\ Faculty of Public Health, Universitas Sumatera Utara, Medan, Indonesia \\ Email: andinaliunputri@gmail.com
}

\begin{abstract}
:
Parkinson's disease attacked millions of people in the world, or about $1 \%$ of the world's total population. The cause of Parkinson's disease is unclear, but one of them is an environmental factor. Environmental factors that lead to this disease is pesticide exposure. The purpose of this research to analyze the relationship of personal hygiene and the household insecticide use with Parkinsonism in farmers. This research was an observational analytic with cross-sectional design. The sample amounted to 60 people and taken by simple random sampling technique. The data obtained through interviews and observations using a questionnaire. This study resulted that $53.3 \%$ of farmers had Parkinsonism. As many as $21.7 \%$ of farmers had poor personal hygiene, and $63.3 \%$ of farmers were household insecticide use. The chi-square test showed that there was a significant relationship between personal hygiene with Parkinsonism $(p=0.0001)$, and there was a significant relationship between household insecticide use with Parkinsonism ( $p=0.001)$.

Keywords:

personal hygiene, insecticide household use, parkinsonism, farmers
\end{abstract}

\section{Introduction}

Parkinson's disease affects millions of people in the world or about 1\% of the world's total population (Noviani et al., 2010). According to the Community based population study in America, more than 1 million people suffer from Parkinson's disease, with a prevalence of 99.4 cases per 100,000 population (Sjahrir, 2007). Research in Lagos hospitals, Southwestern Nigeria, cited the average incidence of Parkinson's disease in men (60 years) and women (65 years) (Okubadejo et al., 2010).

Based on the data from WHO, the incidence of Parkinson's disease in Asia shows there are 1.5 to 8.7 cases per year in China and Taiwan, whereas, in Singapore, Wakayama, and Japan, there are 6.7 to 8.3 cases per year, ranging in age from 60 to 69 years and rarely found in $<50$ years old (Muangpaisan, 2009).

The exact cause of Parkinson's disease is unclear, but it is thought to be caused by multifactors, one of which is environmental factors. The most influential environmental factor for this disease is exposure to pesticides.

Agricultural communities are related to the use of pesticides. Have higher factors for Parkinson's disease (Hanriko et al., 2018).

Pesticides are chemical compounds used to kill pests, including insects, rodents, fungi, and unwanted plants (weeds). Pesticides are used in public health to kill disease vectors, such as mosquitoes, and on agriculture, to kill pests that damage crops. By their nature, pesticides are potentially toxic to other organisms, including humans, and must be used safely and disposed of properly (WHO, 2018). 
Pesticides are used to protect plants against insects, weeds, fungi, and other pests. Pesticides are potentially toxic to humans and can have acute and chronic health effects, depending on the quantity and methods of exposure. These chemicals have been banned from agricultural use in developed countries, but they are still using them in many developing countries (WHO, 2017). Poisoning of pesticides used for agriculture is a significant public health problem in developing countries. Pesticides kill 250,000 to 370,000 people each year due to the poisoning of pesticides that enter through the digestive tract (Dawson, 2010).

Based on data from the World Health Organization (WHO, 2017), at least as many as 20,000 cases die each year due to pesticide poisoning and around 5,000-10,000 workers experience other impacts, such as hepatitis, infertility, disability, parkinsonism, and cancer. While in Indonesia, it is estimated that there are as many as 300,000 cases of poisoning every year and a small percentage of them are fatal. The World Health Organization (2017) estimates that nearly 3 million people are working in agriculture in developing countries who have been exposed to poisons from substances contained in chemical pesticides and each year around 18,000 people die.

Based on a study conducted by Kamalesh Das (2010) titled Role of Familial, Environmental and Occupational Factors in the Development of Parkinson's Disease in West Bengal, India, founded that Exposure to insecticides and pesticides was positive in 90 patients (26.08\%), and 20 controls (5.4\%), and both were significantly associated with the development of Parkinson's disease $(\mathrm{p}=0.049)$. A history of acute organophosphate poisoning was significantly related to the development of Parkinson's disease $(p=0.046)$

High pesticide exposure can occur both on farms and in homes. Exposure to pesticides in the home can occur through the use of insecticides, namely toxic chemicals used to kill insects such as the use of mosquito coils. In Narayan's (2017) study it was found that the frequency of pesticide use in the home, exposure to pesticides in residential ambient areas, and exposure to pesticides in the work environment, each increased the risk of Parkinson's disease by $46 \%$ to $68 \%$. People who have actively used pesticides such as fungicides, insecticides, and herbicides at work have a risk of $29 \%$ to $89 \%$ for Parkinson's disease. Using any pesticide for $>10$ years increases the risk of Parkinson's disease compared to those who do not use pesticides at work.

There have been many previous studies that have proven the relationship between the effects of pesticide use and the incidence of Parkinson's disease. One study conducted by the University of California in 2013 showed that there was a relationship between chemicals used in pesticides, namely paraquat, maneb, and ziram with an increased risk of Parkinson's disease. These chemicals not only poisoning those who work in the fields but also those who live in the vicinity of agricultural areas potentially exposed to these pesticides (Wang et al., 2011). In this study, the researchers found another chemical in pesticides, benomyl, in the brain of patients with Parkinson's disease. These chemicals were banned in the United States 10 years ago by the United States environmental protection agency (EPA) (Wang et al., 2011).

\section{Research Methods}

The type of this research is an analytical epidemiological survey with Cross-Sectional design. The dependent variable of this study was the Parkinsonism. While the independent variables are personal hygiene and household insecticide use which aims to determine the relationship between personal hygiene and household insecticide use with Parkinsonism on farmers who live at Juhar Ginting Sadanioga Village Tanah Karo Regency 2018. 
The population of this study was all people living in Juhar Ginting Sadanioga Village, Juhar District, Karo Regency, who worked as farmers both male and female, namely 765 people. The sample in this study amounted to 60 people who worked as a farmer. With the inclusion criteria, the respondent must be at least 40 years old and work at least five years as a farmer. The reason for the age is Parkinson's disease only happen at people up to 40 years old. The data collected and conducted by interviewing using questionnaires to obtain the sample identity (such as name, age, gender). Personal hygiene and insecticide household use variables are taken using question questionnaires, and Parkinsonism variables received using the PDQ-39 questionnaire.

\section{Discussion}

Juhar Ginting Sadanioga Village is one of the villages in Juhar District, Karo Regency. Juhar Ginting Sadanioga village has an area of $6.76 \mathrm{Km} 2$, with the field of agricultural land of 852 Ha. Based on data from the Karo Regency Central Bureau of Statistics (2017), the number of people who work is 864 people with 765 working as farmers or around $88.54 \%$ of the total working population. Farmers usually grow corn, chocolate, rice, tomatoes, and chili in this area. The number of farmers in the village of Juhar Ginting Sadanioga became respondents was 60 people. The characteristics of farmers can be seen in the table below.

Table 1. Gender Frequency Distribution, Personal Hygiene, Household Insecticide Use, and Parkinsonism in Farmers

\begin{tabular}{lll}
\hline \multicolumn{1}{c}{ Variable } & $\mathbf{n}$ & $\mathbf{\%}$ \\
\hline Gender & & \\
Male & 44 & 73.3 \\
Female & 16 & 26.7 \\
Amount & 60 & 100 \\
Personal Hygiene & & \\
Good & 47 & 78.3 \\
Poor & 13 & 21.7 \\
Amount & 60 & 100 \\
Household Insecticide Use & & \\
No-Risk & 22 & 36.7 \\
Risk & 38 & 63.3 \\
Amount & 60 & 100 \\
Parkinsonism & & \\
Yes & 32 & 53.3 \\
No & 28 & 46.7 \\
Amount & 60 & 100 \\
\hline
\end{tabular}

From Table 1, we can see the distributions of respondents. There are 44 people $(73.3 \%)$ respondents is male, and 16 people $(26.7 \%)$ respondents are female. There are $78.3 \%$ of farmers have good personal hygiene, and as many as $21.7 \%$ of farmers have poor personal hygiene. The distribution of farmers who risked of household insecticide used were 38 people $(63.3 \%)$, and almost all of them used mosquito coils in their house. Moreover, there are 32 farmers $(53.3 \%)$ had Parkinsonism. 
Table 2. Relationship between Personal Hygiene and Household Insecticide Use with Parkinsonism

\begin{tabular}{|c|c|c|c|c|c|c|c|}
\hline \multirow[t]{3}{*}{ Variable } & \multicolumn{4}{|c|}{ Parkinsonism } & & & \multirow{3}{*}{ P-Value } \\
\hline & \multicolumn{2}{|c|}{ Yes } & \multicolumn{2}{|c|}{ No } & \multicolumn{2}{|c|}{ Amount } & \\
\hline & $\mathrm{n}$ & \%) & $\mathrm{n}$ & $\%$ & $\mathrm{~N}$ & $\%$ & \\
\hline \multicolumn{8}{|c|}{ Personal Hygiene } \\
\hline Good & 32 & 68.1 & 15 & 31.9 & 47 & 100 & \multirow[t]{3}{*}{0,0001} \\
\hline Poor & 0 & 0 & 13 & 100 & 13 & 100 & \\
\hline Amount & 32 & 53.3 & 28 & 46.7 & 60 & 100 & \\
\hline \multicolumn{8}{|c|}{ Household Insecticide Use } \\
\hline No Risk & 18 & 81.8 & 4 & 18.2 & 22 & 100 & \multirow[t]{3}{*}{0.001} \\
\hline Risk & 14 & 36.8 & 24 & 63.2 & 38 & 100 & \\
\hline Amount & 32 & 53.3 & 28 & 46.7 & 60 & 100 & \\
\hline
\end{tabular}

Table 2 is bivariate with the chi-square test. It shows that there are 13 farmers who had poor hygiene have Parkinsonism, and from 32 farmers who had good hygiene, 15 of them have parkinsonism. From this table, we can see that there is a relationship between personal hygiene with Parkinsonism $(\mathrm{p}=0.0001)$, OR 95\% CI 0,319 (0,210-0,485). Pesticides can enter the human body through various pathways, namely Dermal Contamination, Inhalation, and from the oral (Djojosumarto, 2008).

Personal hygiene intended to maintain the cleanliness of the body and prevent harmful material from sticking for a long time and absorbed by the skin. It is equally dangerous to suck or eat small amounts of chemicals that can interfere with health (Bakar, 1998).

Frequent exposure by pesticides and poor personal hygiene causes pesticides to enter the human body quickly and over time will accumulate in the body. When the level of pesticides in the body is too high, it will damage the body and cause disease. In line with Priwibowo's (2014) research titled Individual Hygiene, Management and Use of Pesticides on Farmers Against Pesticide Poisoning Levels in Candibinangun Village, Pakem District, Sleman Regency, that there is a relationship between personal hygiene and pesticide use with pesticide poisoning with $\mathrm{p}=$ 0.002, OR value of 11.309 (95\% CI: 2.43-52.61) (Priwibowo, 2014). Also in line with Rusdita's (2016) research, there is a relationship between personal hygiene with the level of pesticide poisoning on farmers in Kembang Kuning Village, Cepogo District, Boyolali Regency in 2016 with a value of $\mathrm{p}=0.038$ (Rusdita, 2016).

Pesticides also affect the central nervous system. Pesticide exposure is consistently associated with the incidence of Parkinson's disease (Freire and Koifman, 2012). Exposure to pesticides can induce oxidative stress and mitochondrial dysfunction and disorders of the ubiquitin-proteasome system, a mechanism associated with neuronal cell death in Parkinson's disease (Rhodes et al., 2013; Terry 2012).

Pesticides also affect the central nervous system. Pesticide exposure is consistently associated with the incidence of Parkinson's disease (Freire and Koifman, 2012). Exposure to pesticides can induce oxidative stress and mitochondrial dysfunction and disorders of the ubiquitin-proteasome system, a mechanism associated with neuronal cell death in Parkinson' disease (Rhodes et al., 2013; Terry 2012). In line with Narayan's (2013) study entitled containing increased chances of Parkinson's disease by $71 \%$ [OR $1 / 41.71$, (95\% CI: 1.21, 2.41)] and the use of organothiophosphate often almost doubled the possibility of Parkinson's disease. 
Personal hygiene (Personal hygiene) is intended to maintain the cleanliness of the body and prevent harmful material from sticking for a long time and absorbed by the skin. It is equally dangerous to suck or eat small amounts of chemicals that can interfere with health (Bakar, 1998).

Most farmers in the village of Juhar Ginting Sadanioga already have good personal hygiene $(78.3 \%)$. There are still many farmers who have poor personal hygiene $(21.7 \%)$ caused by limited knowledge about the effects of pesticide use and exposure to pesticides on the body. However, there are not a few farmers who already know the adverse effects of pesticides but still ignore the importance of maintaining personal hygiene because they feel that no adverse effects have occurred so far. These farmers feel that maintaining their health or not is the same because there are no adverse impacts.

Table 2 shows that there are 38 farmers risked with household pesticide use, and 24 of them have parkinsonism. From 22 farmers who did not risk with household pesticide use, 4 of them have parkinsonism. From this table, we can see that there is a relationship between household pesticide use with Parkinsonism ( $\mathrm{p}=0.001)$, OR 95\% CI 0,288 (0,115-0,722). In line with Narayan's (2013) research based on the case-control study of Parkinson's Disease conducted in California's Central Valley suggests that household pesticide use increases the odds of developing Parkinson's Disease by 47\% [odds ratio (OR) $1 / 41.47$, ( $95 \%$ confidence interval (CI): $1.13,1.92)]$; especially for products that contain Organophosphates as active ingredients independent of occupational and ambient exposures. Moreover, his results are corroborated by finding that carriers of the PON1 192QQ variant or the 55MM-192QQ diplotype using household pesticides are at higher risk than non-carriers who are rarely or un-exposed (Narayan, 2013).

In line with Hancok's (2008) research titled Pesticide exposure and risk of Parkinson's disease: A family-based case-control study that individuals with Parkinson's Disease were significantly more likely to report direct pesticide application than their unaffected relatives (odds ratio $=1.61 ; 95 \%$ confidence interval, 1.13-2.29). Frequency, duration, and cumulative exposure were also significantly associated with PD in a dose-response pattern $(\mathrm{p} \leq 0.013)$. Associations of direct pesticide application did not vary by sex but modified by a family history of Parkinson's Disease, as significant associations restricted to individuals with no family history. When classifying pesticides by functional type, both insecticides and herbicides found to increase the risk of Parkinson's Disease. Two specific insecticide classes, organochlorines, and organophosphorus compounds were significantly associated with Parkinson's Disease. These data corroborate positive associations of broadly defined pesticide exposure with PD in families, particularly for sporadic PD. These data also implicate a few specific classes of pesticides in Parkinson's Disease and thus emphasize the need to consider a more narrow definition of pesticides in future studies (Hancock, 2008).

\section{Conclusion}

There is $53.3 \%$ farmers in Juhar Ginting Sadanioga Village have Parkinsonism. There is a relationship between personal hygiene with Parkinsonism $(p=0.0001)$, OR 95\% CI 0,319 $(0,210$ $0,485)$. There is a relationship between household pesticide use with Parkinsonism $(p=0.001)$, OR 95\% CI 0,288 (0,115-0,722).

We hope that farmers should pay more attention to their hygiene and the habit of using household pesticide. Improving the excellent practice will minimize the risk of exposure to pesticides that can disrupt short-term and long-term human health. 


\section{References}

Dawson AH., Eddleston M., Senarathna L.,2010, Acute Human Lethal Toxicity of Agricultural Pesticides: A Prospective Cohort Study. Journal Plos Medicine Vol 7

Das K., Ghosh M., Nag C., 2010, Role of Familial, Environmental and Occupational Factors in the Development of Parkinson's Disease, Journal Neuro-degenerative Disease, Vol. 8, pp 345-351

Gunnell D, Eddleston M, Phillips MR, Konradsen F (2007) The global distribution of fatal pesticide self-poisoning: a systematic review. BMC Public Health 7: 357. 2.

Gunnell D, Eddleston M (2003) Suicide by intentional ingestion of pesticides: a continuing tragedy in developing countries. Int J Epidemiol 32: 902-909.

Hancock DB., Martin ER., Mayhew GM., 2008, Pesticide exposure and risk of Parkinson's disease: A family-based case-control study, Journal Biomed Central, Vol. 8:6.

Hanriko R., Anzani BP.,2018, Parkinson's Disease: Health Threats for Agricultural Communities. Journal Agromedicine, Vol. 5, pp 508-512.

Muangpaisan W., Hori H., Brayne C., 2009. Systemic Review of the Prevalence and Incidence of Parkinson's Disease in Asia. Journal Epidemiol. 19(6):281-293

Nadesul, Handrawan., 2011, Menyayangi Otak, PT. Kompas Media Nusantara.

Narayan S., Liew Z., Paul K., Pei CL., 2013, Household Organophosphorus Pesticide Use and Parkinson's disease, International Journal of Epidemiology, Vol.42, pp 1476-1485

Nelson LM, Van Den Eeden SK, Tanner CM, Efird JT, Bernstein AL, 2000, Home pesticide exposure and the risk of Parkinson's disease, Jornal of Neurology Vol. 54, pp A472A473.

Noviani E., Gunarto U., Setyono J., 2010. The Relationship Between Smoking With Parkinson's Disease In Rsud. Dr. Margono Soekarjo Purwokerto. Journal Mandala of Health. 4:81-6

Okubadejo N.U., Ojo O.O., Oshinaike O.O., 2010. Clinical profile of Parkinsonism and Parkinson's disease in Lagos, Southwestern Nigeria. Journal of BMC Neurology. 10:1-6

Priwibowo GS., Sunarti.,Dewi FST., 2014, Hygiene Perorangan, Pengelolaan Dan Penggunaan Pestisida Pada Petani Terhadap Tingkat Keracunan Pestisida Di Desa Candibinangun Kecamatan Pakem Kabupaten Sleman, UGM Press.

Rhodes, S.L., Fitzmaurice, A.G., Cockburn, M., Bronstein, J.M., Sinsheimer, J.S., Ritz, B., 2013. Pesticides that inhibit the ubiquitin-proteasome system: effect measure modification by genetic variation in SKP1 in Parkinson's disease. Environ. Res. 126, 1-8.

Rusdita, Aulia, 2016, Hubungan Higiene Perorangan Dan Cara Penyemprotan Pestisida Dengan Tingkat Keracunan Pestisida Pada Petani Di Desa Kembang Kuning Kecamatan Cepogo, UMS.

Sjahrir H., 2007. Parkinson's Disease and Other Movement Disorders. Medan: Pustaka Cendekia pp.54

Wang, A. et al. (2011) 'Parkinson's disease risk from ambient exposure to pesticides', European Journal of Epidemiology, 26(7), pp. 547-555. doi: 10.1007/s10654-011-9574-5. 